\title{
The Impact of Demographic and Academic Characteristics on Academic Performance
}

\author{
Nout M. Alhajraf ${ }^{1} \&$ Aishah M. Alasfour ${ }^{1}$ \\ ${ }^{1}$ Accounting Department, College of Business Studies, the Public Authority for Applied Education and Training, \\ Kuwait \\ Correspondence: Nout M. Alhajraf, Accounting Department, College of Business Studies, the Public Authority \\ for Applied Education and Training, Kuwait. E-mail: nmfalhajraf2010@gmail.com
}

Received: January 7, 2014

Accepted: January 27, 2014

Online Published: March 26, 2014

doi: 10.5539/ibr.v7n2p92

URL: http://dx.doi.org/10.5539/ibr.v7n2p92

\begin{abstract}
The purpose of this study is to explore students' demographic and academic characteristics that are associated with students' academic performance during their undergraduate studies. Demographic and academic characteristic such as age, gender, nationality, high school major and high school GPA were studied as potential determinants of academic performance. A sample of 700 students from the College of Business Studies at the Public Authority for Applied Education was examined. Descriptive statistics, T-test and multiple regressions were used. The results of the study reveal that students' age, gender, high school major and high school GPA are significantly related to students' academic performance. Our research has some implications. The findings reveal that student's age, gender, high school major and high school GPA are significantly related to business students' academic performance. Interestingly, the findings highlight the positive and significant influence of science background on the academic performance of business students. This study contributes to the literature of the undergraduates business students academic performance. The findings of this study may be useful for education sector, educators, college's management and future researchers.
\end{abstract}

Keywords: demographic, academic performance, college of business, Kuwait

\section{Introduction}

Student performance is naturally considered a critical aspect for many educationists and others since a long period. Therefore, many papers looked at specific factors particularly affecting student's academic performance to determine these factors that have major impact on learner performance. Academic performances for both undergraduate and postgraduate students have been a considerable attention. As a result, universities and colleges should address this issue and focus on improving the quality of students which will have a positive impact on students and society.

This research examines the performance of business students in the Business College at the Public Authority for Applied Education in Kuwait attempting to determine the most important demographic and academic characteristics influencing students' performance, and using these to make recommendations for future research and development. In predicting students' performance, previous researchers considered various factors that are associated with students' success such as study effort, attendance, and quality of teaching, age and academic skills. In our study, we extend previous research by examining various factors such as age, gender, nationality, high school major and high school GPA in examining students' performance. Thus, the objective of this study is to explore all these factors and determine if they are significantly related to students' academic success across the areas of accounting, information systems, business management, material management, law, banking, and insurance among students enrolled at the College of Business Studies, at the Public Authority for Applied Education.

The paper is organized as follows. The next section of this paper provides a background through reviewing various pieces of literatures that examine similar variables that may have impact on students' academic performance. Next, we describe the data selected from 700 undergraduate students across different majors. Using a sample of 420 female students and 280 male students, studying at the College of Business Studies in Kuwait, various variables identified in the literature as having impact on the student performance were examined. T-test and regression were used to analyze the data. The subsequent section describes the method developed and 
applied in the student's efforts which is used in analyzing the data to revel the association between these parameters and students performance. Then, the following section presents the results and offers an analysis while relating findings to the literature. Finally, recommendations and conclusions are also provided to outline the implications of the study, the direction of future research and the limitations.

\section{Literature Review}

Numerous researchers and experts have attempted to determine what factors do influence student performance in academic environments, with many of these researchers focusing on performance in the college environment. While various factors have been found to be influential, researchers continue to pursue additional research efforts for clarity, as the representativeness of the sample is typically assumed to be a limitation and the sheer amount of personal and environmental variables make it difficult to determine which factors are more likely to affect students in general.

Kaighobadi and Allen (2008) attempted to determine the academic success factors of business students, focusing on factors potentially influencing their performance. They targeted gender, age, ethnicity, and other demographic and academic variables. They found that student performance is strongly correlated with demographics, "but the strongest predictors of overall academic success are the grades the students receive in core knowledge courses that are typically taken in the earlier semesters of business students' plans of study" (Kaighobadi \& Allen, 2008, p. 427). More specifically, and importantly, their study also confirmed that demographic variables can be influential, as traits such as age, gender, or ethnicity had been shown to be correlated to academic success. As some have argued that these factors do not influence academic success, aside from randomness or perhaps another factor making it incidental like poverty, these findings warrant additional research, and the development of strategies to counteract academic achievement imbalances due to such standard characteristics.

There is some empirical evidence that shows the impact of gender on the students' academic performance. Gammie et al. (2003) and Kaighobadi and Allen (2008) found that females earned higher grades than males in Accounting and Auditing subjects. Whereas, Cullen et al. (2004) confirmed that females outperform males in Math and English courses. Nguyen et al. (2005) and Sheard (2009) investigated the relationship between the gender (male and female) and students' achievements. Both studies found that performance is associated with variables such as student gender. In 2011, Al-Mutairi examined the association of some factors such as gender and age with the student General Point Average (GPA) at Arab Open University (AUO) - Kuwait. The study indicated that both factors play a significant role in determining students GPA. In the same year Garkaz et al. tested student gender in The Islamic Azad University and reached the same conclusion which revealed that female students have better academic performance than male students. Recently, Sarwar and Sarwar (2012) investigated the students' performance in University of Punjab, Pakistan by testing students' gender as a parameter to determine the relationship between gender and students GPA. Most of the prior academic research arrived at the same conclusion that females perform and achieved better grades than males in the course at university. These analyses have reported a significant correlation between gender and academic performance of business students. However, according to the previous academic study by Lipe (1989) which indicated that there is no any significant impact of gender on student academic performance. Lipe found males outperformed females if the instructor is male and vice versa. Also, there is strong evidence that gender is a statically insignificant factor that is affected negatively on the students' success (Laband \& Piette, 1995).

Cohn (1972), Simpson and Sumrall (1979) and Guney (2009) conducted studies about the link between the students age and students academic performance. They found that mature students achieve higher grades than youthful students do. This result demonstrates a positive relationship between students' age and their GPA. However, this is inconsistent with some other studies which reveal that grades earned by younger students are higher than mature students (Lane \& Porch, 2002; Diaz, 2003; Roos, 2009; Al-Mutairi, 2011). The fact that mature students have other responsibilities than study and that may lead to poor performance comparing with young students who concern about their study only.

While very little academic research has attempted to investigate the affect of students' nationality on their GPA, at least a few studies have shown a significant positive relationship between nationality and students performance (Bachan \& Reilly, 2003; Hartnett et al., 2004). According to the study by Sue and Okazaki (1990) who investigates the Asian students' performance in USA and why they have higher performance. The results show that there is a significant positive correlation between students' performance and their origin countries. Also, Harb and El-Shaarawi (2007) used data collected from business students in United Arab Emirates (UAE) from both national and non-national students to determine if the nationality is one of the factors that has influence on the students' GPA. Their findings came to the same conclusion that non-national students earned 
higher grades than national students and these may related to their education system and learning styles at their origin countries.

The relation between high school major and undergraduates' business student's performance has been investigated in the literature. Researchers have largely agreed that students with science background fare better academically than do their counterparts with art background (Cumhur Erdem, 2007; Garkaz et al., 2011). This study takes into account the influence of math skills on the business students performance as the students with math diploma perform better than students without math diploma. The findings of their research reveal that high school major (science and art) have a significant correlation with the students GPA. In addition, the study conducted by Bartlett et al. (1993), Gull and Fong (1993) and Naser and Peel (1998) students with accounting background from the high school act better in the intermediate accounting subjects than students without any basic in accounting. Arrington and Cheek (1990) and Kaighobadi and Allen (2008) found that choosing a major is a significant indicator associated with the students GPA. Moreover, Kaighobadi and Allen (2008) evaluated the students' performance in different majors. Their findings point out those students undertaking Economics and International Business earned higher grade point average than students choosing managements. According to their study, there is a positive relation between the academic success and choosing the appropriate field. Therefore, students who are interested in accounting career outperform students non-interested in accounting career (Cohen \& Hannon, 1993; Garkaz et al., 2011).

Other influential factors discovered by Guney (2009) included GCSE (General Certificate of Secondary Education) grades, which were then recommended to be considered as "very strong determinants of performance," having implications for admissions policies and attempting to determine academic outcomes . Meanwhile, the variation in success of the business students led Guney (2009) to believe that policy makers should have more perspective into student achievements, monitoring it periodically, possibly changing policies as needed (such as changing entry requirements) (Guney, 2009).

Other researchers have continued to either elaborate on known relationships or attempt to discover new ones. Clark and Latshaw (2012) discussed the study of student achievement and influences, stating that this is common in research ranging from standardized testing (such as the SAT or ACT) as well as in basic studies of academic achievement in universities. They confirmed that student effort was strongly correlated with student performance, concluding their efforts "support the universal importance of student effort on academic performance regardless of course content" (Clark \& Latshaw, 2012, p. 19).

In conclusion, the factors that influence on undergraduates business students performance is debatable in previous literature reviews that we perceive. Despite this, they still recommended that future research efforts attempt to examine these variables in greater depth. This current study attempts to investigate some factors that could influence on the students' academic achievements in a developing country, Kuwait by examining students nationality, age, gender, college GPA, high school major and high school GPA.

\section{Data and Methodology}

\subsection{Data Collection}

The population used in this study is comprised of students enrolling at the College of Business Studies at the Public Authority for Applied Education and Training, Kuwait in the Spring semester of 2012-2013. The College of Business Studies is a two-year college that offers seven majors; namely, Accounting, Banking, Information Technology, Insurance, Law, Management, and Material's Management. The aim of this paper is to investigate students' demographics likely to influence business students' academic performance. For this purpose, data about student's demographics were obtained from the Registration and Records Office at the College of Business Studies. Data collected comprised of student's nationality, age, gender, college GPA, high school major and high school GPA.

\subsection{Statistical Analysis Methods}

Data collected from the Registration and Records Office were analyzed using quantitative methods. Descriptive statistics, independent sample t-tests and multiple regression analyses were used to identify the relative importance of student's demographics likely to influence business students' performance. Ordinary least squares regression analysis was used, with the dependent variable being the students' college grade point averages (CGPA), as a proxy for academic performance. Five independent students' demographics variables were included in the regression model to capture the potential influence of student's demographics on the College of Business Studies students' performance. The regression model is as follows:

$$
\text { CGPA } \left.=\beta_{0}+\beta_{l} \text { (Nationality }\right)+\beta_{2}(\text { Age })+\beta_{3}(\text { Gender })+\beta_{4}(\text { High School Major })+B_{5}(\text { High School GPA })+\varepsilon
$$




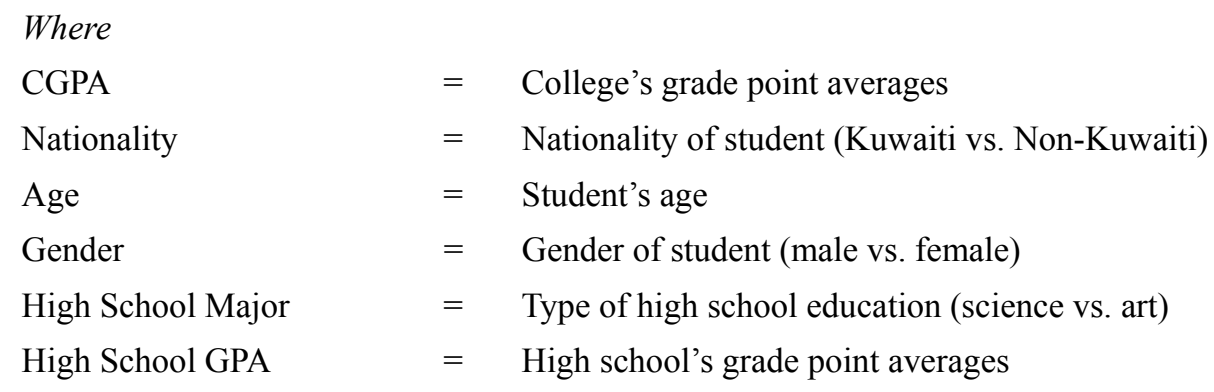

\section{Results and Discussion}

Table 1 provides a description of students' demographics. It shows that the sample population was comprised of 280 males $(40 \%)$ and 420 females $(60 \%)$. Among the total of 700 students, $199(28.4 \%)$ were Non-Kuwaitis as compared with 501(71.6\%) Kuwaitis. Table 1 shows that only 224 students $(32 \%)$ majored in science in high school, while 476 students (68\%) had an art major in high school. In addition, Table 1 presents the frequency distribution of student high school' GPAs. It shows that $4 \%$ of the students achieved a GPA below $60 \%$, whereas $47 \%$ of students achieved a high school's GPA between $60 \%$ and $70 \%$. Also, $43 \%$ of the student sample achieved a GPA between $71 \%$ and $80 \%$ in high school. Surprisingly, $1 \%$ of the students investigated in this study achieved a high school GPA above $90 \%$.

In addition, Table 1 shows that $28 \%$ of the students investigated in this study were between 18 and 20 years old, $38 \%$ were between 21 and 23 years old, 13\% were between 24 and 26 years old, $9 \%$ were between 27 and 29 years old and $12 \%$ were 29 years or older. The distribution of student college's GPAs shows that $28 \%$ of students achieved a GPA below 2.00, whereas $26 \%$ of students achieved a GPA between 2.00 and 2.49 . Also, $34 \%$ of the student investigated achieved a GPA between 2.5 and 3.5. Only $12 \%$ of the students investigated in this study achieved a GPA above 3.50 .

Table 1. Characteristics of sample student population

\begin{tabular}{lcc}
\hline Variable & N & Percentage \\
\hline Gender & 280 & 40.0 \\
Male & 420 & 60.0 \\
Female & 700 & 100 \\
Total & & \\
Nationality & 501 & 71.6 \\
Kuwaiti & 199 & 28.4 \\
Non-Kuwaiti & 700 & 100 \\
Total & & \\
Type of High School Education & 476 & 68.0 \\
Art & 224 & 32.0 \\
Scientific & 700 & 100 \\
Total & & \\
High School GPA & 28 & 4.0 \\
Below 60\% & 329 & 47.0 \\
$60 \%-70 \%$ & 301 & 43.0 \\
$71 \%-80 \%$ & 35 & 5.0 \\
$81 \%-90 \%$ & 7 & 1.0 \\
Above $90 \%$ & 700 & 100 \\
Total & & \\
\hline
\end{tabular}




\begin{tabular}{lcc}
\hline Age & & 28.0 \\
$18-20$ & 196 & 38.0 \\
$21-23$ & 266 & 13.0 \\
$24-26$ & 91 & 9.0 \\
$27-29$ & 63 & 12.0 \\
Above 29 & 84 & 100 \\
Total & 700 & 28.0 \\
College GPA & & 26.0 \\
Below 2.00 & 196 & 20.0 \\
$2.00-2.49$ & 182 & 14.0 \\
$2.50-2.99$ & 140 & 12.0 \\
$3.00-3.50$ & 98 & 100 \\
Above 3.50 & 84 & 700 \\
Total
\end{tabular}

Note. This table shows the characteristics of sample student population investigated in the study.

Table 2 provides the results of t-tests conducted to determine whether there were significant differences between students' demographic backgrounds and academic performances. The results presented in Table 2 show that significant $(p<0.01)$ gender differences exist in academic performance, as female students enrolled at the College Business Studies have academically outperformed male students. This could be partially attributed to the fact that female students are less socially active in the Kuwaiti environment and thus have more time to study as compared with male students. In addition, Table 2 shows a significant $(p<0.10)$ difference in academic performance between Kuwaiti and Non-Kuwaiti students, as Non-Kuwaiti students academically outperform Kuwaiti students. This finding may indicate that Non-Kuwaiti students take their studies more serious than Kuwaiti students do. Furthermore, Table 2 shows a significant $(p<0.01)$ difference in academic performance between students with a science background and an art background, as students with a science background perform academically better than students with an art background do. This finding could be partially explained on the grounds that students with a science background tend to take more and higher-level mathematics classes in high school, which likely helps them perform better in business classes.

Table 2. T-test for differences among students' demographics with respect to academic performance

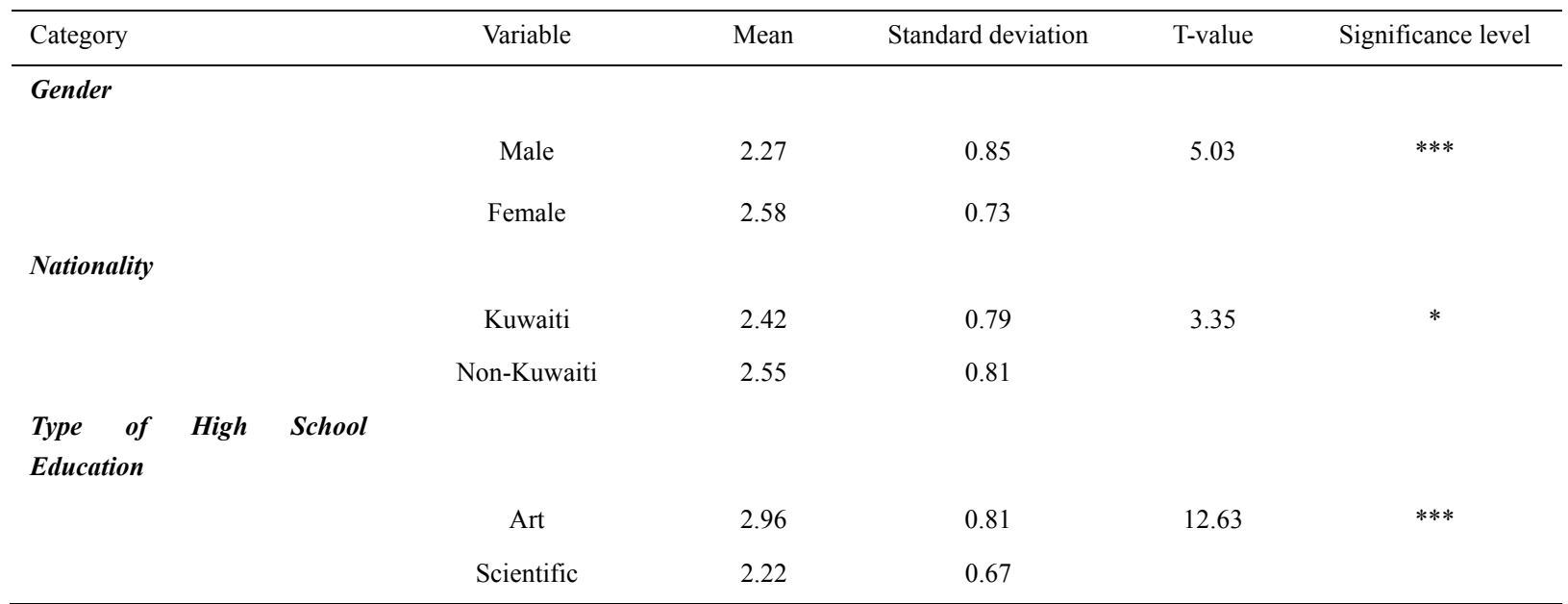

Note. This table shows the differences among the sample characteristics with respect to academic performance. $* \& * * *$ indicate significant at 0.10 and 0.01 levels respectively. 
The relationship between determinants of academic performance (as measured by students' demographics; namely, nationality, age, gender, high school major, and high school GPA) and academic performance (as measured by college GPA) was investigated using the Pearson product-moment correlation coefficient. Preliminary analyses were performed to ensure no violation of the assumptions of normality, linearity, multicollinearity and homoscedasticity. Table 3 present Pearson's correlations among all variables included in the study. The correlation matrix shows that no pair-wise correlation coefficient exceeds 0.8 , suggesting that multicollinearity is unlikely to be a serious problem in interpreting the multiple regression results (Gujarati, 2003).Variance inflation factors (VIF) were also examined and found to be well within acceptable limits.

Table 3. Bivariate correlations among all variables included in the study

\begin{tabular}{|c|c|c|c|c|c|c|}
\hline Variable & College GPA & Nationality & Age & Gender & $\begin{array}{l}\text { High School } \\
\text { Major }\end{array}$ & $\begin{array}{c}\text { High School } \\
\text { GPA }\end{array}$ \\
\hline College GPA & 1 & & & & & \\
\hline Nationality & .073 & 1 & & & & \\
\hline Age & $.299 * * *$ & .041 & 1 & & & \\
\hline Gender & $.187^{* * *}$ & $-.132 * * *$ & $-.134 * * *$ & 1 & & \\
\hline High School Major & $-.431 * * *$ & $-.124 * * *$ & $-.223 * * *$ & -.016 & 1 & \\
\hline High School GPA & $.219 * * *$ & $.408 * * *$ & $-.139 * * *$ & $.089 * *$ & -.060 & 1 \\
\hline
\end{tabular}

Note. This table shows the bivariate correlations among all variables included in the study. $* *, * * *$ indicate significant at the 0.05 , and 0.01 levels respectively (two-tailed).

Table 4 shows that the multiple regression model is highly significant $(p<0.000, \mathrm{~F}=66.284)$. The adjusted $\mathrm{R}^{2}$ of the regression model reveals that students' demographics identified as likely influencing business students' performance in this study explain about $32 \%$ of the association between students' performance in College of Business Studies and the potentially influential student's demographics. According to the regression results presented in Table 4, the age $(p<0.01)$, gender $(p<0.01)$, high school major $(p<0.01)$, and high school GPA ( $p$ $<0.01)$ variables are significantly and positively related to business students' academic performance. In comparing the impact of the students' demographics identified as potentially affecting business students' academic performance, the standardized coefficient beta presented in Table 4 shows that high school major (science vs. art) has the strongest impact on students' performance $(\beta 0.358)$, followed by student's age $(\beta 0.281)$, followed by high school GPA ( $\beta 0.243)$, followed by student's gender $(\beta 0.190)$. Student's nationality variable is associated with the lowest standardized coefficient beta $(\beta$ 0.057), suggesting the weak impact of student's nationality on the academic performance of business students.

Table 4. Multivariate regression analysis results

\begin{tabular}{|c|c|c|c|c|c|}
\hline \multirow{2}{*}{ Variable } & \multicolumn{2}{|c|}{ Unstandardized Coefficient } & \multirow{2}{*}{$\begin{array}{c}\begin{array}{c}\text { Standardized } \\
\text { Coefficient }\end{array} \\
\text { Beta }\end{array}$} & \multirow{2}{*}{$t$-statistic } & \multirow{2}{*}{ Significance } \\
\hline & B & Std. Error & & & \\
\hline Intercept & -0.163 & 0.371 & & -0.138 & \\
\hline Nationality & -0.100 & 0.062 & -0.057 & -1.615 & \\
\hline Age & 0.044 & 0.005 & 0.281 & 8.584 & $* * *$ \\
\hline Gender & 0.308 & 0.052 & 0.190 & 5.908 & $* * *$ \\
\hline High School Major & -0.610 & 0.055 & -0.358 & -11.061 & $* * *$ \\
\hline High School GPA & 0.032 & 0.005 & 0.243 & 6.930 & $* * *$ \\
\hline $\mathbf{N}$ & $\mathbf{R}^{2}$ & Adj. $R^{2}$ & $F$-statistic & $p$-value $(I$ & istics) \\
\hline 700 & 0.323 & 0.318 & 66.284 & & \\
\hline
\end{tabular}

Note. This table shows the multivariate regression analysis results. $* * *$ indicates significant at the 0.01 . 
Among the independent variable included in our model, some comparisons with the finding of previous studies can be made. The results of this research reveal that the College of Business Studies at the Public Authority for Applied Education should consider about their students' academic performance and how they can increase the education college level. The findings of this study indicate that undergraduate students' performance does not meet the expectations. The study shows a significant difference between Science major students and Art major students in terms of GPA. The GPA of students in Science major tends to be higher than the GPA of students in Art major. In other words, the technical skills that students earned in the high school stage for Science students have a positive impact on their performance over the study period.

The College of Business Studies and Administration should concern about undergraduate admission policies and they need to encourage student to improve their performance and help them to learn effectively. As the results of this study show that High School GPA matters, the Administration of the College of Business Studies is encouraged to revisit entry requirements and establish a new acceptance policy such as requiring a higher GPA and reject students with GPA below $60 \%$. Thus, the higher high school GPA is a good indicator to determine the students' academic performance. The higher high school GPA is the better academic performance. From the data analysis we found that the highest high school GPA was $96.60 \%$ whereas the lowest high school GPA was $54.70 \%$ which is very low percentage. Faculty should consider changing the entry requirement and increase the qualification level to accept only students with high school GPA greater than $60 \%$.

In addition, our results indicate that the student major GPA is relatively low comparing with their general GPA. A potential justification of this finding could be explained on the ground that students have not chosen there major correctly and those not interested in studying it. This finding is consistent with previous studies (Cohen \& Hannon, 1993; Garkaz et al., 2011) that the student who is interested in accounting has a positive impact and highly performance comparing with student who is not interested in the same field. Thus, the faculty may want to take further step by encouraging students to choose the major which is more enjoyable and that will influence their academic performance positively.

Another interesting finding is that genders perform differently as there is a relation between gender and students' performance. There is a significant difference between male performance and female performance as measured by GPA. This study similar to previous studies (Sheard, 2009; Al-Mutairi, 2011) in finding that females' achievement is higher than males' with mean around to 2.57 and 2.27 respectively. In general, our results seem to explain whether the demographic and academic characteristics are correlated with the students' performance. In testing these factors we found that all factors except nationality are significantly related to the students GPA.

\section{Conclusion}

The review of the empirical literature on evaluating students' performance outline some academic success factors for undergraduate students and the effective of these factors in improving the students' academic achievements. Within this context, the objective of this study is to explore the effect of students' demographic and academic characteristics on students' academic performance. Particularly, this study examines some of demographic and academic characteristics such as students age, gender, nationality, high school major, high school (GPA) and whether they are correlated with the students' performance. The sample for this study is drawn from the official records system at the College of Business Studies in the Spring semester of 2012-2013. We obtained a total of 700 students from seven majors divided into 280 males and 420 females. To meet the purpose of the current study, we used T-test and regression analysis to analyze the data and determine which demographic and academic characteristics are associated with students GPA.

In the present study we find that student's age, gender, high school major, and high school GPA are significantly associated with the students' GPA. In order to improve the performance of undergraduate business students at the College of Business Studies we provide some recommendations in the line with our findings. Therefore, the study suggests that the faculty should focus on new undergraduate students before starting their first year by providing foundation course. This course should contain a math subject and an introductory subject in each major. Enrolling in this course prior to choosing a specific major will contribute to better preparation for success in their chosen major. By completing this program students will improve their academic level and expand their knowledge by knowing and understanding a lot of new concepts and theories in business. Also, it will give them the opportunity to choose the suitable major that satisfy their motivations.

Another reason that is related to the poor student performance is students' interest by choosing their major at the College of Business Studies. The Registration department at the College of Business Studies does not give students the opportunity to choose their field and that may be referring to a large number of students applying to the college and the acceptance policy. Therefore, the study also suggests that faculty should focus on a low major 
GPA which indicates a lack of academic performance. In addition, poorly performing students may associate with class sizes. The small number in the class is important factor to maximize the educator performance. The results of this research support the idea that policy makers at the College of Business Studies should reduce the capacity of classes from 60 to 40 students which will improve students understanding and teaching quality as it consistent with previous findings. More specifically, as the abilities of professors and abilities for students to communicate with them were proven to affect performance.

This work contributes to existing knowledge about business students performance by providing an assessment of students' performance at the College of Business Studies among seven majors and determining the factors that influence on the students performance. The current findings provide a feedback about the students' performance at the College of Business Studies in Kuwait to the college's management, academic communities and future researchers who are interested in improving the efficiency of students' performance. These findings add substantially to our understanding of how effective the demographic and academic characteristics are in students' academic performance. As with any research, certain limitations should be considered when interpreting the results. First, the validity of this research is limited because the sample was taken from one business college (PAAET) so that the results cannot be applied to other colleges and universities. Moreover, this research studies some factors affected students' performance while there other factors are not covered such as employment, marital status, and family role in choosing major and other probable factors. The implications of this study may be useful for the College of Business studies (faculty and administration) and future researcher to develop their future strategies in changing the admission policy in order to improve the quality of education.

\section{Acknowledgements}

The authors thank the Editor and the anonymous referees for their valuable comments and suggestions that have improved the quality of this study.

\section{References}

Al-Mutairi, A. (2011). Factors Affecting Business Students' Performance in Arab Open University: The Case of Kuwait. The International Journal of Business and Management, 6(5), 146-155.

Arrington, L. R., \& Cheek, J. G. (1990). Scope and student achievement in agribusiness and natural resources education. Journal of Agricultural Education, 31(2), 55-61. http://dx.doi.org/10.5032/jae.1990.02055

Bachan, R., \& Reilly, B. (2003). A comparison of academic performance in A-level economics between two years. International Review of Economics Education, 2(1), 8-24.

Bartlett, S., Pell, J. M., \& Pendlebury, M. W. (1993). From fresher to finalist: a three year analysis of student performance on an accounting degree programme. Accounting Education: An International Journal, 2(2), $111-122$.

Clark, S., \& Latshaw, C. (2012). "Peeling the Onion" Called Student Performance: An Investigation into the Factors Affecting Student Performance in an Introductory Accounting Class. Review of Business, 33(1), $19-27$.

Cohen, J., \& Hanno, D. M. (1993). An analysis of underlying constructs affecting the choice of accounting as a major. Issues in Accounting Education, 8(2), 219-238.

Cohn, E. (1972). Students' characteristics and performance in economic statistics. Journal of Economic Education, 3(2), 106-111. http://dx.doi.org/10.2307/1181996

Cullen, M., Hardison, C., \& Sackett, P. (2004). Using SAT-grade and ability-job performance relationships to test predictions from stereotype threat theory. Journal of Applied Psychology, 89(2), 220-230. http://dx.doi.org/10.1037/0021-9010.89.2.220

Díaz, A. (2003). Personal, family, and academic factors affecting low achievement in secondary school. Electronic Journal of Research in Educational Psychology and Psychopedagogy, 1(1), 43-66.

Erdem, C., Şentürk, I., \& Arslan, C. K. (2007). Factors affecting grade point average of university students. The Empirical Economics Letters, 6(5), 360-368.

Gammie, E., Paver, B., Gammie, B., \& Duncan, F. (2003a). Gender differences in accounting education: an undergraduate exploration. Accounting Education: An International Journal, 12(2), 177-196.

Garkaz, M., Banimahd, B., \& Esmaeili, H. (2011). Factors Affecting Accounting Students' Performance: The Case Of Students At The Islamic Azad University. Procedia-Social and Behavioral Sciences, 29, 122-128.

Gull, F., \& Fong, S. (1993). Predicting success for introductory accounting students; some further Hong Kong 
evidence. Accounting Education: An International Journal, 2(1), 33-42.

Guney, Y. (2009). Exogenous and Endogenous Factors Influencing Students' Performance in Undergraduate Accounting Modules. Accounting Education, 18(1), 51-73. http://dx.doi.org/10.1080/09639280701740142

Harb, N., \& El-Shaarawi, A. (2007). Factors Affecting Students' Performance. Journal of Business Education, 282-290. Retrieved January 25, 2014, from http://mpra.ub.uni-muenchen.de/13621/

Hartnett, N., Ro"mcke, J., \& Yap, C. (2004). Student performance in tertiary-level accounting: an international student focus. Accounting and Finance, 44(2), 163-185. http://dx.doi.org/10.1111/j.1467-629X.2004.00104.x

Kaighobadi, M., \& Allen, M. (2008). Investigating Academic Success Factors for Undergraduate Business Students. Decision Sciences Journal of Innovative Education, 6(2), 427-436. http://dx.doi.org/10.1111/j.1540-4609.2008.00184.x

Laband, D. N., \& Piette, M. L. (1995). Does who teaches principles of economics matter? American Economic Review, 85, 335-338.

Lane, A., \& Porch, M. (2002). The impact of background factors on the performance of nonspecialist undergraduate students on accounting modules - a longitudinal study: a research note. Accounting Education: An International Journal, 11(1), 109-118.

Lipe, M. G. (1989). Further evidence on the performance of female versus male accounting students. Issue in Accounting Education, 4(1), 144-152.

Naser, K., \& Peel, M. J. (1998). An exploratory study of the impact of intervening variables on student performance in a principles of accounting course. Accounting Education: An International Journal, 7(3), 209-223.

Nguyen, N. T., Allen, L., \& Fraccastoro, K. (2005). Personality predicts academic performance: exploring the moderating role of gender. Journal of Higher Education Policy and Management, 27(1), 105-116. http://dx.doi.org/10.1080/13600800500046313

Pomykalski, J., Dion, P., \& Brock, J. (2008). A Structural Equation Model for Predicting Business Student

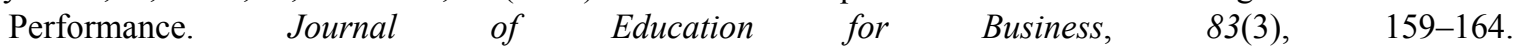
http://dx.doi.org/10.3200/JOEB.83.3.159-164

Roos, S. (2009). Factors affecting southern African students' success in CIMA examinations. Meditari Accountancy Research, 17(1), 49-67. http://dx.doi.org/10.1108/10222529200900004

Sarwar, A., \& Sarwar, S. M. (2012). Factors Having Impact on the Performance of Business Students Case study of Institute of Business and Information Technology (IBIT). International Journal of Business and Social Science, 3(17), 279-293.

Sheard, M. (2009). Hardiness commitment, gender, and age differentiate university academic performance. British Journal of Education Psychology, 79, 189-204. http://dx.doi.org/10.1348/000709908X304406

Simpson, W., \& Sumrall, B. (1979). The determinants of objective test scores by finance students. Journal of Financial Education, Fall, 58-62.

Stockly, S. (2009). Is Race a Determinant of Student Performance in Economics? Review of Black Political Economy, 36(3/4), 181-195. http://dx.doi.org/10.1007/s12114-009-9046-2

Sue, S., \& Okazaki, S. (1990). The Asian-American educational achievement: a phenomenon in search of explanation. American Psychologist, 45(8), 913-920. http://dx.doi.org/10.1037/0003-066X.45.8.913

\section{Copyrights}

Copyright for this article is retained by the author(s), with first publication rights granted to the journal.

This is an open-access article distributed under the terms and conditions of the Creative Commons Attribution license (http://creativecommons.org/licenses/by/3.0/). 